\title{
МЕХАНІЗМ РОЗВИТКУ ВУГЛЕДОБУВНОЇ ГАЛУЗІ УКРАЇНИ У ЗОВНІШНЬОЕКОНОМІЧНІЙ СФЕРІ В КОНТЕКСТІ ПРОБЛЕМ ЕНЕРГЕТИЧНОЇ БЕЗПЕКИ
}

\section{THE MECHANISM FOR UKRAINIAN COAL SECTOR DEVELOPMENT IN THE FOREIGN ECONOMIC SPHERE IN THE CONTEXT OF ENERGY SECURITY ISSUES}

\author{
Дятлова Валентина Василівна \\ доктор економічних наук, профессор, \\ Донецький державний університет управління \\ ORCID: https://orcid.org/0000-0003-3414-8225 \\ Єрохіна Діна Олександрівна \\ викладач, \\ Донецький державний університет управління \\ ORCID: https://orcid.org/0000-0002-1556-9879 \\ Чмихов Дмитро Олександрович \\ студент, \\ Донецький державний університет управління \\ ORCID: https://orcid.org/0000-0002-3889-9176
}

\author{
Diatlova Valentyna, Yerokhina Dina, Chmykhov Dmytro \\ Donetsk State University of Management
}

\begin{abstract}
Встановлено сучасні тенденції у вугледобувній галузі країни, структурі видобутку кам'яного вугілля. Доведено значимість вугілля в енергетичному балансі. Акцентовано увагу на зовнішньоекономічній діяльності галузі, взаємозв'язку видобутку з імпортом вугілля. Визначено країни - партнери з експорту та імпорту вугілля кам'яного й антрациту. Показано зміну в рамках державної енергетичної політики України щодо спрямованості видатків з держбюджету на підтримку та реформування вугільної галузі, а саме анулювання покриття витрат із собівартості готової вугільної продукції та введення видатків на ліквідацію неперспективних вугледобувних підприємств. Підкреслено проблеми державного сектору, пов'язані з реструктуризацією. Обґрунтовано використання в механізмі розвитку вугледобувної галузі лізингу та кредитування.

Ключові слова: енергетичний баланс, вугледобувна галузь, зовнішньоекономічна сорера, тенденції та проблеми, механізм розвитку, лізинг, кредитування.
\end{abstract}

Установлены современные тенденции в угледобывающей отрасли страны, структуре добычи каменного угля. Доказана значимость угля в энергетическом балансе. Акцентировано внимание на внешнеэкономической деятельности отрасли, взаимосвязи добычи с импортом угля. Определены страны - партнеры по экспорту и импорту угля каменного и антрацита. Показано изменение в рамках государственной энергетической политики Украины относительно направленности расходов из госбюджета на поддержку и реформирование угольной отрасли, а именно аннулирования покрытия расходов по себестоимости готовой угольной продукции и введение расходов на ликвидацию неперспективных угледобывающих предприятий. Подчеркнуты проблемы государственного сектора, связанные с реструктуризацией. Обосновано использование в механизме развития угледобывающей отрасли лизинга и кредитования.

Ключевые слова: энергетический баланс, угледобывающая отрасль, внешнеэкономическая ссрера, тенденции и проблемы, механизм развития, лизинг, кредитование.

The article has been proves the importance of the coal industry for the economy and its significant role in the energy balance of Ukraine. However, a limited number of scientific works are devoted to the problems of development of coal industry, in particular in the sphere of foreign economic activity. State projects for the development of the Ukrainian coal industry in the short term do not provide for the export of coal. Therefore, the purpose of the study was 
to identify the problems and development mechanism of the coal industry in the foreign economic sphere. Current trends in the reduction of coal production, in particular by public and private sectors, changes in its structure have been established. Attention is focused on the balance of foreign economic activity of the industry, the relationship between the volumes of coal production and import. The countries-partners in export of coal and anthracite (Russian Federation, Moldova, Poland, Romania, Slovakia, and Hungary) and import (Kazakhstan, Russian Federation, Great Britain, Germany, Poland, African countries) have been identified. It is substantiated that in the situation of a decrease in coal production in Ukraine, its sale for export at lower prices than import prices is unprofitable. Therefore, export operations are currently economically impractical. Expenditures from the state budget to support and reform the coal industry in 2015-2019 have a general tendency to increase - almost 3 times. But this does not change the situation regarding the crisis in the coal industry, mainly due to state-owned mines, which are mostly unprofitable. Currently, there have been changes in the state energy policy of Ukraine related to the focus of state budget expenditures on the support and reform of the coal industry, namely the cancellation of costs for finished coal products and the introduction of costs for the liquidation of unpromising coal mining companies. The use of modern financial instruments in the mechanism of development of the coal mining industry, such as leasing, lending at the expense of cheap resources of foreign banks, attraction of non-state investors for increase of coal production at joint production activity is substantiated.

Keywords: energy balance, coal industry, foreign economic sphere, tendencies and problems, development mechanism, leasing, crediting.

Постановка проблеми. Вугільна промисловість $€$ однією з базових галузей економіки, яка відіграє значну роль в енергетичному балансі України. Вугільна галузь вже тривалий час перебуває в кризовому стані. Ситуація загострилася з 2014 року, враховуючи, що майже половина шахт знаходилася на непідконтрольній території (45,3\% за даними на 2020 р.) [1]. Це спричиняє скорочення видобутку вугілля, зміну в тенденціях і балансі зовнішньоекономічної діяльності. Наразі $\epsilon$ загроза згортання вуглевидобутку на більшості шахт протягом одного - двох років, що не може не вплинути на енергетичний баланс, в тому числі в зовнішньоекономічний сфрері, a загалом на енергетичну безпеку країни.

Аналіз останніх досліджень і публікацій. Розвиток вугледобувної галузі для забезпечення енергетичної безпеки країни $€$ предметом підвищеної уваги з боку українського уряду, про що свідчить прийняття програмних документів, починаючи з 90-х років і до останнього десятиріччя [2; 3]. Проблемам реформування, структурних перетворень, визначення стратегічних напрямів розвитку вугледобувної галузі присвячено праці вітчизняних вчених - О. Амоші, А. Кабанова, Л. Стариченка [4], В. Ляшенка, Є. Котова [5], В. Красника [6].

Виділення невирішених раніше частин загальної проблеми. Проблемам розвитку підприємств вугледобувної галузі, зокрема в сорері зовнішньоекономічної діяльності, присвячено обмежене коло праць, зокрема щодо розроблення та запровадження відповідних механізмів. Слід також враховувати, що наразі як серед науковців, так і серед політиків та представників влади немає єдності у поглядах щодо подальшого розвитку вітчизняної вугільної промисловості, особливо з позицій загальноєвропейської тенденції переходу до «зеленої» енергетики [7].

Формулювання цілей статті (постановка завдання). Метою дослідження є визначення проблем та механізму розвитку вугільної промисловості у зовнішньоекономічній сорері.

Виклад основного матеріалу дослідження. Вугільна промисловість довгий час була і до цих пір залишається однією з базових галузей економіки України. В структурі енергетичного балансу вугілля займає близько третини загального обсягу надходжень первинної енергії (в 2019 році - 29\%) і майже чверть у загальному обсязі первинних енергоресурсів власного виробництва [8]. Значимість вугледобувної галузі в енергетичній безпеці обумовлена також тим, що 3 щорічного видобутку необробленого (рядового) вугілля, який становив з 2001 по 2013 роки близько 80 млн т, майже дві третини використовувалося в електро- та теплоенергетиці.

ЗагальніресурсивугілляУкраїнистановлять: 112,3 млрд т, розвідані запаси - 51,9 млрд т, 3 них коксівного вугілля - 17,1 млрд т (30,5 \%), антрацитів - 7,6 млрд т (13,5\%). Запаси вугілля коксівного та антрацитів становлять відповідно 31,5 \% та 14,3 \% від запасів кам'яного вугілля України [9].

Значне скорочення видобутку вугілля відзначено з 2014 року через політичні дії на Сході країни. Так, обсяги видобутку вугілля в 2019 році становили 37\% від обсягів 2013 року (рис. 1). Це вплинуло на собівартість видобутку вугілля, перш за все на шахтах державної фрорми власності: з 2015 по 2019 роки собівартість зросла вдвічі - 32,68 тис. грн. до 4,258 тис. грн. за тонну. 3148 шахт 102 пере- 


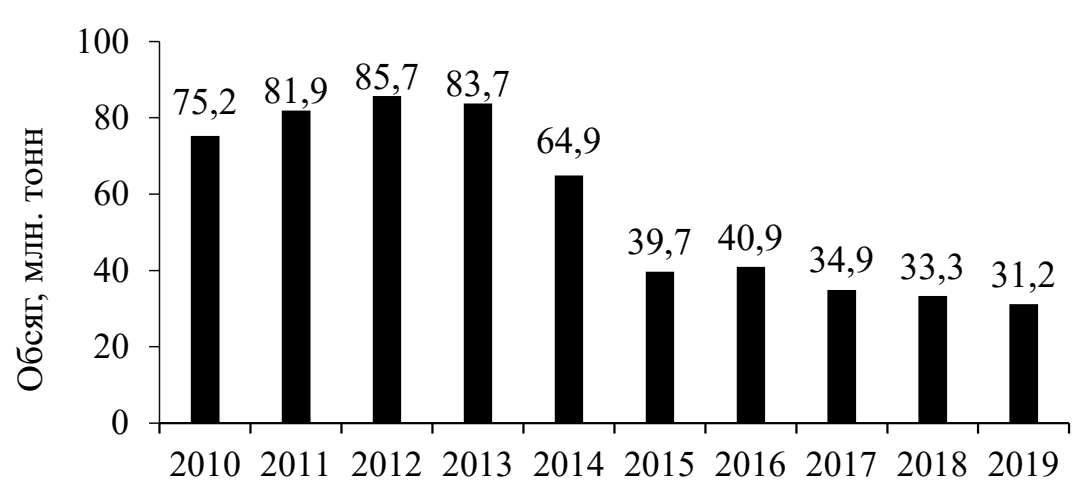

Роки

Рис. 1. Видобуток кам'яного вугілля в Україні в 2010-2019 роках ${ }^{1}$

${ }^{1}$ Не враховано видобуток на окупованій території України з 2014 року [1]

бувають у державній власності, 3 них 67 - на непідконтрольній території, 33 - діючі (4 прибуткові), 2 - не діючі [1].

Обсяг видобутку вугілля приватними шахтами $€$ набагато більшим, ніж державних (табл. 1) [1], і існує тенденція до збільшення їх частки: у 2015 р. $-82,9 \%, 2017$ р. $-86,2 \%$, 2019 р. $-88,8 \%$. Переважно добувається енергетичне вугілля, наприклад, в 2019 р. - 79,8\%, 3 нього приватними шахтами - 71,2\%.

Видатки 3 держбюджету на підтримку та реформування вугільної галузі за 2015-2019 роки мають загальну тенденцію до збільшення - майже в 3 рази (табл. 2) [1]. Однак на підтримку вугледобувних підприємств, а саме на часткове покриття витрат із собівартості готової вугільної продукції, кошти виділено тільки по 2018 рік включно, найбільше - в 2017 році, а в подальшому такої статті не передбачено. Видатки на реструктуризацію вугільної галузі за аналізований період постійно змінюються, найбільші спостерігаються в 2019 році, але темп приросту $є$ меншим, ніж у попередні два роки. 32018 року виділяють кошти і на ліквідацію неперспективних вугледобувних підприємств, однак в 2019 році їх зменшено на 12\%, а в 2020 році сума коштів осталася без змін.
Україна, через скорочення видобутку вугілля, зменшує експорт і збільшує імпорт (табл. 3) [10]. 32011 по 2018 роки в кількісному виразі імпорт вугілля кам'яного та антрациту збільшився в 1,7 разів, експорт зменшено в 109,6 разів. У сумовому виразі імпорт вугілля кам'яного та антрациту збільшився за аналізований період в на 1,1 разів, експорт зменшено в 89,6 разів, і це з урахуванням зменшення імпортної ціни (в 1,5 разів) та збільшення експортної (в 1,2 разів). Аналогічні тенденції відзначено за експортно-імпортними операціями за такими товарними позиціями, як кокс, напівкокс, вугілля ретортне.

Експортні ціни на вугілля кам'яне та антрацит $\epsilon$ нижчими, ніж імпортні (відповідно, 141,9 і 135,6 дол за тонну). Це дозволяє констатувати, що експортні операції $€$ неефективними (виключенням $є$ співвідношення експортних і імпортних цін у 2017 році). У ситуації зниження видобутку вугілля в Україні його продаж на експорт за нижчими цінами, ніж імпортні, взагалі $\epsilon$ збитковим, тому експортні операції слід вважати економічно недоцільними. Однак використання підходу з визначення зони критичного ризику для показника покриття імпорту зовнішньої торгівлі експор-

Таблиця 1

Структура видобутку кам'яного вугілля в Україні в 2015-2019 роках

\begin{tabular}{|l|c|c|c|c|c|}
\hline \multicolumn{1}{|c|}{ Показники видобутку } & $\mathbf{2 0 1 5}$ p. & $\mathbf{2 0 1 6}$ p. & $\mathbf{2 0 1 7}$ p. & $\mathbf{2 0 1 8}$ p. & $\mathbf{2 0 1 9}$ p. \\
\hline Державні шахти, млн. т, в т.ч. & 6,8 & 5,8 & 4,8 & 4,2 & 3,5 \\
\hline енергетичне вугілля & 4,8 & 4,2 & 3,9 & 3,6 & 2,7 \\
\hline коксоване вугілля & 2,0 & 1,6 & 0,9 & 0,6 & 0,8 \\
\hline Приватні шахти, млн. т, в т.ч. & 32,9 & 35,1 & 30,1 & 29,1 & 27,7 \\
\hline енергетичне вугілля & 26,6 & 28,3 & 24,2 & 23,9 & 22,2 \\
\hline коксоване вугілля & 6,3 & 6,8 & 5,9 & 5,2 & 5,5 \\
\hline Усього & 39,7 & 40,9 & 34,9 & 33,3 & 31,2 \\
\hline
\end{tabular}


Таблиця 2

Видатки з держбюджету на підтримку та реформування вугільної галузі

\begin{tabular}{|c|c|c|c|c|c|c|}
\hline Показник & 2015 p. & 2016 p. & 2017 p. & 2018 p. & 2019 p. & $2020 \mathrm{p}$. \\
\hline $\begin{array}{l}\text { Видатки на підтримку вугледобувних } \\
\text { підприємств на часткове покриття } \\
\text { витрат із собівартості готової вугільної } \\
\text { продукції, } \\
\text { млн. грн. } \\
\% \text { до попереднього року }\end{array}$ & $\begin{array}{c}400 \\
- \\
\end{array}$ & $\begin{array}{c}1120 \\
180\end{array}$ & $\begin{array}{c}1729 \\
54\end{array}$ & $\begin{array}{c}1400 \\
-19 \\
\end{array}$ & - & $\begin{array}{l}- \\
-\end{array}$ \\
\hline $\begin{array}{l}\text { Видатки на реструктуризацію } \\
\text { вугільного галузі, } \\
\text { млн. грн. } \\
\text { \% до попереднього року }\end{array}$ & $\begin{array}{c}1093,9 \\
-\end{array}$ & $\begin{array}{c}305,6 \\
-72\end{array}$ & $\begin{array}{c}568,1 \\
86\end{array}$ & $\begin{array}{c}1300 \\
129\end{array}$ & $\begin{array}{c}2630 \\
102\end{array}$ & $\begin{array}{c}3562,7 \\
35,5\end{array}$ \\
\hline $\begin{array}{l}\text { Видаткиналіквідаціюнеперспективних } \\
\text { вугледобувних підприємств, } \\
\text { млн. грн. } \\
\text { \% до попереднього року }\end{array}$ & - & - & - & $\begin{array}{c}752,9 \\
-\end{array}$ & $\begin{array}{c}659,7 \\
-12\end{array}$ & $\begin{array}{c}659,7 \\
0\end{array}$ \\
\hline Усього, млн. грн. & 1493,9 & 1425,6 & 2297,1 & 3452,9 & 3289,7 & 4222,4 \\
\hline
\end{tabular}

том товарів та послуг за умови його нормального розподілу надає можливість обґрунтовано приймати рішення щодо експорту вугілля [11]. Прогнозування енергетичного балансу повинно базуватися на тенденціях переходу до інноваційної економіки, а саме розвитку відновлювальної енергетики [12].

В Україні експорт вугілля здійснюються через національного оператора вугільного ринку - ДП «Вугілля України». Кам'яне вугілля експортувалося у 2018 році в країни Європейського Союзу і Співдружності Незалежних Держав у співвідношенні 30:70 (рис. 2). 3 країн СНД експорт вугілля здійснювався в Російську Федерацію (40,8\%) і Молдову $(29,1 \%) .3$ країн $€ С$ українське вугілля купували Польща, Румунія, Словаччина, Угорщина. Цього ж року українські підприємства купували кам'яне вугілля переважно у країн СНД (72,1\%), а саме Казахстані і Російській Федерації. Частка країн ЄС у таких операціях становила менше одного відсотка. Майже третину імпорту вугілля припадає на країни Асррики і американського континенту.

Експортувався український антрацит тільки в країни ЄС, а саме в Польщу (табл. 4). Імпортувався антрацит з Російської Федерації (93,6\%), країн Афррики і Південної Афррики $(6,3 \%)$. Обсяги імпорту в країни $€ C$ (Велика Британія, Німеччина, Польща) в чотири рази менше експорту.

На жаль, усі проекти розвитку вугільної промисловості в Україні на короткострокову перспективу не передбачають експорту вугілля. В той же час, Австралія, Індонезія, Росія, Китай і ЮАР, частка яких становить $70-80 \%$

Динаміка показників експорту та імпорту вугілля кам'яного, антрациту

Таблиця 3

(код товарної позиції 2701)

\begin{tabular}{|c|c|c|c|c|c|c|c|}
\hline Роки & $\begin{array}{c}\text { Обсяг } \\
\text { імпорту, } \\
\text { млн т }\end{array}$ & $\begin{array}{l}\text { Вартість } \\
\text { імпорту, } \\
\text { млн дол }\end{array}$ & $\begin{array}{c}\text { Ціна } \\
\text { імпорту, } \\
\text { дол/т }\end{array}$ & $\begin{array}{c}\text { Обсяг } \\
\text { експорту, } \\
\text { млн т }\end{array}$ & $\begin{array}{c}\text { Вартість } \\
\text { експорту, } \\
\text { млн дол }\end{array}$ & $\begin{array}{c}\text { Ціна } \\
\text { експорту, } \\
\text { дол/т }\end{array}$ & $\begin{array}{c}\text { Частка } \\
\text { експорту у } \\
\text { загальному } \\
\text { обсязі } \\
\text { видобутку, } \\
\%\end{array}$ \\
\hline 2011 & 12,708782 & 2760,897 & 217,243242 & 6,990843 & 775,109 & 110,874897 & 12,9 \\
\hline 2012 & 14,764238 & 2637 & 178,609150 & 6,114 & & 99,67 & \\
\hline 2013 & 14,207715 & 1973,751 & 138,921072 & 8,537365 & 737,009 & 86,327456 & 15,8 \\
\hline 2014 & 14,697342 & 1773,195 & 120,647325 & 7,046549 & 521,017 & 73,939314 & 18,0 \\
\hline 2015 & 14,598166 & & 112,603391 & & & 95,272681 & \\
\hline 2016 & 15,647557 & 1467,091 & 93,758470 & & & 85,984037 & \\
\hline 2017 & 19,777741 & 2744,062 & 138,744966 & 0,635760 & 105,494 & 165,933686 & 3,3 \\
\hline 2018 & 21,387573 & 3035,349 & 141,921152 & 0,063798 & 8,649 & 135,568513 & \\
\hline
\end{tabular}

${ }^{1}$ Укладено та розраховано за даними Держстату України [10] 


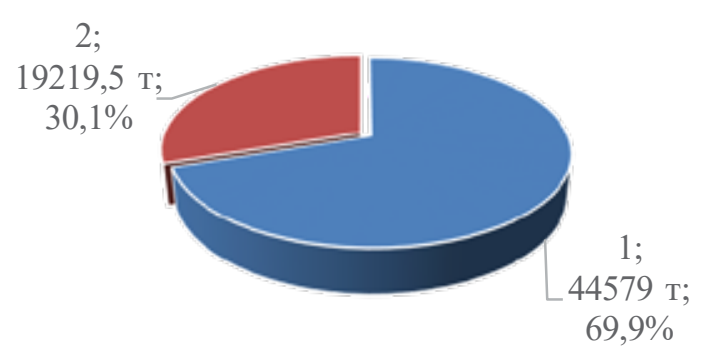

експорт

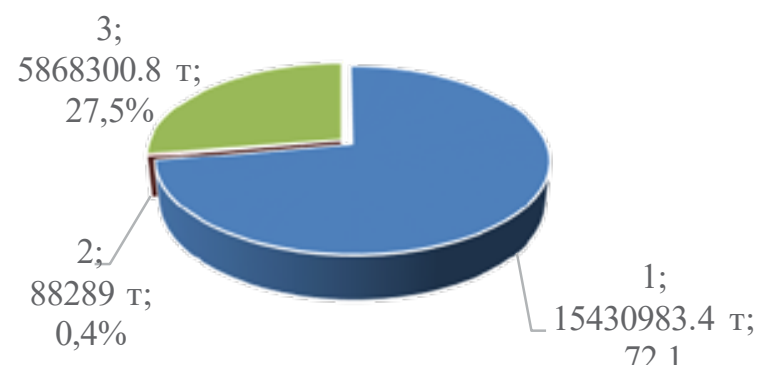

імпорт
72,1

Рис. 2. Експорт і імпорт кам'яного вугілля в Україні в 2018 році:

1 - країни СНД; 2 - країни ЄС; 3 - інші країни

Джерело: розраховано за даними Держстату України [10]

експортних постачань в інші країни, лише нарощують темпи експорту, хоча і не мають таких природних запасів, як Україна. Попит же на вугілля диктують Китай і Індія, економіка яких активно розвивається. Найбільшими імпортерами вугілля на азійському ринку $\epsilon$ Японія, Південна Корея, Індія і Тайвань, а на європейському - Німеччина і Велика Британія. Разом $з$ тим, провідні виробники вугілля, a саме США і КНP, є як експортерами, так і імпортерами. Китай $€$ нетто-імпортером вугілля 32006 р., а Японія $€$ найбільшим імпортером вугілля.

Експортний потенціал вугільної промисловості реалізується переважно недержавним сектором. Державний сектор $€$ більшим за кількістю, але не за видобутком: частка шахт, які належать до Міненерго України, становить 70\% від загальної їх кількості, а видобуток вугілля на них, наприклад у 2019 році - лише $11,4 \%$, за вісім місяців 2020 року цей показник знизився до 9,8\% [1].

Оскільки приватизувалися, піддавалися оренді та концесії саме рентабельні шахти, що згодом утворили приватний сектор, у державній власності осталися проблемні вугільні підприємства. Основними проблемами державного сектору є: низька продуктивність праці (нижча, ніж у 1940-х роках), збитко- вість (тільки близько 40\% витрат на виробництво покривається за рахунок доходу від реалізації продукції), значна кредиторська заборгованість (ії обсяг більше $80 \%$ річної вартості виробленої продукції). Збитки шахт державної фрорми власності не покриваються державними субсидіями та дотаціями, і держава їх постійно збільшує. 32018 року державна політика у вугільній галузі змінилася - з'явилися державні видатки на ліквідацію неперспективних вугледобувних підприємств, анульовано покриття витрат по собівартості готової вугільної продукції (див. табл. 2). Такий механізм дозволить відновити стратегічну роль вугільної галузі в енергетичній безпеці України.

У 2020 році презентовано проект Концепції рефрормування вугільної галузі, що буде реалізуватися в 2020-2024 роки. Це вже четвертий за останні 15 років концептуальний документ, відповідно до якого має здійснюватися реструктуризація вугільних підприємств, усуватимуться існуючі в державному секторі галузі проблеми. Основним механізмом передбачено організаційний - інтегрування шахт державної форми власності до ПАТ «Центренерго» для забезпечення потреб внутрішнього ринку за рахунок українського вугілля, а також приватизацію окремих шахт.

Експорт і імпорт антрациту в Україні в 2018 році

\begin{tabular}{|c|c|c|c|c|}
\hline \multirow{2}{*}{ Країни } & \multicolumn{2}{|c|}{ Експорт } & \multicolumn{2}{|c|}{ Імпорт } \\
\hline & кількість, т & частка, \% & кількість, т & частка, \% \\
\hline Країни СНД & - & - & 3624136,3 & 93,69 \\
\hline Країни ЄС & 120,0 & 100,0 & 27,9 & 0,01 \\
\hline Інші країни & - & - & 245355,0 & 6,3 \\
\hline Усього & 120,0 & 100,0 & 3869519,2 & 100,0 \\
\hline
\end{tabular}

Джерело: розраховано за даними Держстату України [10] 
Але механізм розвитку для відновлення експортного потенціалу не передбачений.

У процес інтегрування будуть включені тільки шахти за певним переліком. Діяльність шахт, що включені до другої групи, не обмежуватиметься тепловою генерацією. Шахти, включені до третьої групи, будуть підпадати під приватизацію і не лише як вугледобувні підприємства, але й за рахунок майна для використання в різних сорерах господарської діяльності. Крім того, передбачено скорочення використання вугільної продукції в енергетиці як відповідність Європейському курсу на «зелену» економіку. Звідси, збільшені обсяги вугільної продукції, яка не буде затребувана на внутрішньому ринку, може експортуватися.

Для реалізації наміченого необхідно матеріально-технічне переоснащення шахт, але в умовах обмежених видатків 3 держбюджету на підтримку та реформування вугільної галузі вугледобувні підприємства повинні самостійно приймати рішення і використовувати сучасні фонінансові інструменти щодо залучення інвестицій. Українські виробники гірничошахтного устаткування працюють на умовах, що $є$ невигідними для вуглевидобувних підприємств, зокрема щодо характеру оплати (як правило, повної передоплати), гарантійного обслуговування й ін. Крім того, кредитні ставки вітчизняних банків $є$ високими для вуглевидобувних підприємств. У такій ситуації з сучасних фрінансових інструментів можна використовувати лізинг гірничошахтної техніки, кредитування за рахунок дешевих ресурсів закордонних банків. Крім того, можна залучати кошти українських і закордонних недержавних інвесторів за умов спільної підприємницької діяльності, зокрема міжнародного виробничого кооперування.
Висновки. У статті доведено значимість вугільної промисловості для економіки та її значну роль в енергетичному балансі України. Встановлено сучасні тенденції скорочення видобутку кам'яного вугілля, зміни в його структурі, обсягах за державним і приватним секторами. Акцентовано увагу на балансі зовнішньоекономічної діяльності галузі, взаємозв'язку обсягів видобутку та імпорту вугілля. Визначено країни - партнери 3 експорту (Російська Федерація, Молдова, Польща, Румунія, Словаччина, Угорщина) та імпорту (Казахстан, Російська Федерація, Велика Британія, Німеччина, Польща, країни Асррики) вугілля кам'яного й антрациту. Обґрунтовано, що в ситуації зниження видобутку вугілля в Україні його продаж на експорт за нижчими цінами, ніж імпортні, є збитковим. Видатки з держбюджету на підтримку та рефрормування вугільної галузі за 2015-2019 роки мають загальну тенденцію до збільшення - майже в 3 рази. Але це не змінює ситуації щодо кризового стану вугледобувної галузі, переважно через шахти державної форми власності, які у більшості $€$ збитковими. Наразі відбулися зміни в державній енергетичній політиці України, пов'язані зі спрямованістю видатків з держбюджету на підтримку та ресрормування вугільної галузі, а саме 3 анулюванням покриття витрат по собівартості готової вугільної продукції та введення видатків на ліквідацію неперспективних вугледобувних підприємств. Обґрунтовано використання в механізмі розвитку вугледобувної галузі сучасних фрінансових інструментів, таких як лізинг, кредитування за рахунок дешевих ресурсів закордонних банків, залучення недержавних інвесторів для збільшення видобутку вугілля при спільній виробничій діяльності.

\section{СПИСОК ВИКОРИСТАНИХ ДЖЕРЕЛ:}

1. Вугільна галузь в Україні : кількість шахт і рівень видобутку. Слово і діло : аналітичний портал. URL: https://media.slovoidilo.ua/media/infographics/11/109749/109749-1_uk_large.png

2. Концепція ресормування та розвитку вугільної промисловості на період до 2020 року : розпорядження Кабінету Міністрів України від 24 травня 2017 р. № 733-p. URL: https://zakon.rada.gov.ua/laws/show/733-2017-\%D1\%80\#Text

3. Енергетична стратегія України на період до 2035 року «Безпека, енергоефективність, конкурентоспроможність» : Розпорядження Кабінету Міністрів України від 18.08.2017 p. № 605-p. URL: https://zakon.rada.gov.ua/ laws/show/605-2017-\%D1\%80\#Text

4. Формування та реалізація державної політики стосовно вугільної промисловості з урахуванням інтеграції України в світову економіку : монографрія / О.І. Амоша, А.І. Кабанов, Л.Л. Стариченко [та ін.]. Донецьк : Інститут економіки промисловості, 2013. 196 с.

5. Ляшенко В.І., Котов Є.В. Україна XXI: неоіндустріальна держава або «крах проекту»? : монографрія. Київ : Інститут економіки промисловості, 2015. 196 с.

6. Красник В.Г. Основні напрями рефрормування вугільної промисловості України на середньострокову перспективу. Розробка родовищ : Збірник наукових праць. 2015. Т. 9. С. 25-34. 
7. Diatlova V., Petryk I. Strategic approach to renewable energy development: EU experience. Центральноукраїнський науковий вісник. Економічні науки. 2019. Вип. 2(35). С. 9-19. URL: https://doi.org/10.32515/2663-16 36.2019.2(35).9-19

8. Енергетичний баланс України за 2019 рік : Експрес випуск державної статистичної служби України. 30.11.2020. URL: https://www.ukrstat.gov.ua

9. Дятлова В.В., Гордієнко В.І., Єрохіна Д.О. Вугільна промисловість України: сучасний стан, проблеми та перспективи. Проблеми та перспективи забезпечення стабільного соціальноекономічного розвитку : Збірник наукових праць ДонДУУ. Серія «Економіка». Маріуполь : ДонДУУ, 2017. Т. XVIII. C. 9-16.

10. Динаміка виробництва, експорту, імпорту вугілля в Україні : Статистична інфрормація. URL: http://www.ukrstat.gov.ua

11. Fokina-Mezentseva K., Melnyk T., Diatlova V., Buhas V., Shatska Z. Determination of the Critical Risk Zone for the Indicator of Foreign Trade Import Coverage by the Export of Goods and Services Subject to its Normal Distribution. International Journal of Scientific \& Technology Research. 2020. Volume 9, Issue 03. Pp. 4843-4847.

12. Дятлова В.В., Петрик І.В. Сучасні підходи до розвитку відновлювальної енергетики як складової інноваційної економіки України. Економіка і організація управління. 2019. № 2(34) С. 20-27.

\section{REFERENCES:}

1. Vuhilna haluz v Ukraini: kilkist shakht i riven vydobutku. Slovo i dilo: analitychnyi portal [Coal industry in Ukraine: the number of mines and the level of production. Word and business: analytical portal]. URL: https://media.slovoidilo.ua/media/infographics/11/109749/109749-1_uk_large.png (in Ukrainian)

2. Kontseptsiia reformuvannia ta rozvytku vuhilnoi promyslovosti na period do 2020 roku: rozporiadzhennia Kabinetu Ministriv Ukrainy vid 24.05.2017 № 733-r [Concept of reforming and developing the coal industry for the period up to 2020 : Order of Cabinet of Ministers of Ukraine dated 24.05.2017 no 733-r]. URL: https://zakon.rada.gov.ua/ laws/show/733-2017-\%D1\%80\#Text (in Ukrainian)

3. Enerhetychna stratehiia Ukrainy na period do 2035 roku «Bezpeka, enerhoefektyvnist, konkurentospromozhnist»: Rozporiadzhennia Kabinetu Ministriv Ukrainy vid 18.08.2017 № 605-r [Energy strategy of Ukraine for the period up to 2035 "Security, energy efficiency, competitiveness": Order of the Cabinet of Ministers of Ukraine dated 18.08.2017 no. 605-r]. URL: https://zakon.rada.gov.ua/laws/show/605-2017-\%D1\%80\#Text (in Ukrainian)

4. Amosha O.I. and et. (2013) Formuvannia ta realizatsiia derzhavnoi polityky stosovno vuhilnoi promyslovosti z urakhuvanniam intehratsii Ukrainy $v$ svitovu ekonomiku : monohrafiia [Formation and implementation of state policy in relation to the coal industry, taking into account the integration of Ukraine into the world economy: a monograph]. Donetsk: Institute of Industrial Economics, 196 p. (in Ukrainian)

5. Liashenko V.I., Kotov Ye.V. (2015) Ukraina XXI: neoindustrialna derzhava abo «krakh proektu»?: monohrafiia [Ukraine XXI: neo-industrial state or "project collapse"?: monograph]. Kyiv: Institute of Industrial Economics, 196 p. (in Ukrainian)

6. Krasnyk V.H. (2015) Osnovni napriamy reformuvannia vuhilnoi promyslovosti Ukrainy na serednostrokovu perspektyvu [The main directions of reforming the coal industry of Ukraine in the medium term]. Development of coal depositdeposits: Collection of scientific works, vol. 9, pp. 25-34. (in Ukrainian)

7. Diatlova V., Petryk I. (2019) Strategic approach to renewable energy development: EU experience. Central Ukrainian Scientific Bulletin, Economic sciences, issue 2(35), pp. 9-19.

8. Enerhetychnyi balans Ukrainy za 2019 rik: Ekspres vypusk derzhavnoi statystychnoi sluzhby Ukrainy [Energy balance of Ukraine for 2019: Express issue of the State Statistical Service of Ukraine]. 30.11.2020. URL: https://www.ukrstat.gov.ua (in Ukrainian)

9. Diatlova V.V., Hordiienko V.I., Yerokhina D.O. (2017) Vuhilna promyslovist Ukrainy: suchasnyi stan, problemy ta perspektyvy [Coal industry of Ukraine: current state, problems and prospects]. Problems and prospects of ensuring stable socio-economic development: Collection of scientific works of DonSUM, Economics series, vol. XVIII, pp. 9-16. (in Ukrainian)

10. Dynamika vyrobnytstva, eksportu, importu vuhillia v Ukraini: Statystychna informatsiia [Dynamics of production, export, import of coal in Ukraine: Statistical information]. URL: http://www.ukrstat.gov.ua (in Ukrainian)

11. Fokina-Mezentseva K., Melnyk T., Diatlova V., Buhas V., Shatska Z. (2020) Determination of the Critical Risk Zone for the Indicator of Foreign Trade Import Coverage by the Export of Goods and Services Subject to its Normal Distribution. International Journal of Scientific \& Technology Research, vol. 9, issue 03, pp. 4843-4847.

12. Diatlova V.V., Petryk I.V. (2019) Suchasni pidkhody do rozvytku vidnovliuvalnoi enerhetyky yak skladovoi innovatsiinoi ekonomiky Ukrainy [Modern approaches to the development of renewable energy as a component of the innovative economy of Ukraine]. Economics and organization of management, no. 2(34), pp. 20-27. (in Ukrainian) 